\title{
The link between transformational leadership and the team performance in China through big data analysis
}

\author{
Mingxi Peng \\ Dalian Polytechnic University, Liao Ning, China
}

\begin{abstract}
Transformational leadership as one kind of management field increasingly affects the performance of an organization. The paper aims to explore the link between transformational leadership and team performance through big data approach, and examine whether the transformational leadership can be adopted appropriately in Chinese labor intensive enterprise' management practice.
\end{abstract}

\section{INTRODUCTION}

Leadership is an important element of management, which impact the performance of an organization. It is a special interpersonal influence. Everyone in the organization influences others and accepts their influence. Therefore, every employee has potential and realistic leadership. In the organization, leaders and members jointly push the team towards the established goals, which constitute an organic system, within the system has the following several factors: the leader's personality traits and leadership, the staff's subjective initiative, the positive interaction between leaders and employees, the process of the making and implementation of organizational goals. Transformational leadership as a more parallel leadership structure is increasingly popular in organization management. The early research of transformational leadership has an obvious individualorientation characteristic that researchers have shown

can improve an individual's performance through broadening and increasing the interest of their subordinates and satisfying their demand (Bass, 1990) ${ }^{[1]}$. Some researchers intend to use specific components of transformational leadership such as individually considerate or inspirational motivation as the mediator to test the link of transformational leadership-team performance proposition (Dionne et al., 2004) ${ }^{[2]}$. In those studies. However, the view that regards employees as individuals ignores the organization's character that it is a whole. To explore the relationship between transformational leadership and team performance, the study examines the link between those two factors in an empowerment approach. From the analysis before, the study gains the hypothesis:

The transformational leadership promotes team performance through an empowerment approach.

\section{The Model of Study}

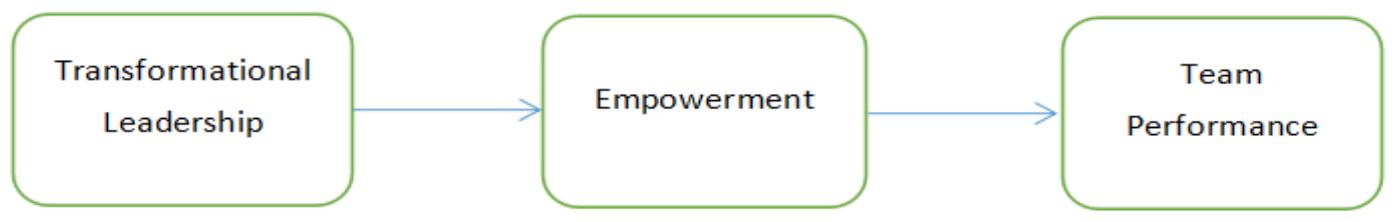

FIGURE I RESEARCH MODEL

Through the model above, it shows the relationships among transformational leadership, empowerment and team performance.

\section{Questionnaire design}

Questionnaire was adopted in this study for the purpose to collect large amount number of data effectively. The questionnaire is constructed in two parts with 29 questions. The first part is designed to collect the basic demographic information about participants. It includes 4 questions ranging from gender, age, work position and group. The main context in the second part is divided into three dimensions in accordance with the variables in this study, which includes transformational leadership, empowerment and team performance. The 5-points Likert Scale is adopted in this study where 1 represents "Strongly Disagree" and 5 indicates "Strongly Agree". To collecting the data, the questionnaire is design into digital format and spreads through Wechat. 


\section{Sampling}

Sample is a subset of all the population which participant into the research (Bell et al., 2018) ${ }^{[3]}$. The research object in this study is all the teams of the environmental sanitation enterprise case, but it remains impossible to collect the data from all of the employees in a limited time that the organization has about 10,000 employees across different areas. This study uses a cluster sampling method to collect data from seven different regional branches. In more detail, the researcher chose one cleaning team in each local branch separately. In total,
300 questionnaires were recollected successfully with 288 returning as valid.

\section{Data analysis}

\subsection{Respondents Profile}

For the purpose of representing the basic information characteristic of 288 samples from collected data, a description of samples is listed in table 1, based on the questions 1 to 4 from questionnaire.

TABLE I. SAmpling DeScriptive (N=288)

\begin{tabular}{|c|c|c|c|}
\hline Variable & Items & $\mathrm{N}$ & Percent (\%) \\
\hline Gender & $\begin{array}{l}\text { Male } \\
\text { Female }\end{array}$ & $\begin{array}{l}125 \\
163\end{array}$ & $\begin{array}{l}43.4 \\
56.6\end{array}$ \\
\hline Age & $\begin{array}{l}\text { Below } 30 \\
30-40 \\
40-50 \\
\text { Over } 50\end{array}$ & $\begin{array}{l}1 \\
13 \\
150 \\
124\end{array}$ & $\begin{array}{l}0.3 \\
4.5 \\
52.1 \\
43.1\end{array}$ \\
\hline Work Position & $\begin{array}{l}\text { Team leader } \\
\text { Membership }\end{array}$ & $\begin{array}{l}7 \\
281\end{array}$ & $\begin{array}{l}2.4 \\
97.6\end{array}$ \\
\hline Group & $\begin{array}{l}\text { Team } 1 \\
\text { Team } 2 \\
\text { Team } 3 \\
\text { Team } 4 \\
\text { Team } 5 \\
\text { Team } 6 \\
\text { Team } 7\end{array}$ & $\begin{array}{l}40 \\
31 \\
40 \\
52 \\
35 \\
30 \\
60\end{array}$ & $\begin{array}{l}13.3 \\
10.3 \\
13.3 \\
18.1 \\
11.7 \\
10.0 \\
20.8\end{array}$ \\
\hline
\end{tabular}

The study was conducted in one representative Chinese environmental sanitation company, "Beijing Hui Feng Qing Xuan., Ltd". There were 288 valid questionnaires collected successfully. From table 1, it shows the number of female participants was more than male participants. The proportion of females who finished questionnaire was 56.6 while the proportion of males was 43.4. That conform to the theory of Gupta (1993) $)^{[4]}$ that females prefer services due to their physical factors. The age distribution of participants had an obvious aging characteristic that the percentage of participants who were $40-50$ was 52.1 and the percentage of participants who were over 50 was 43.1 . Just 4.8 percent participants were below 40 . That mainly due to the reason that the middle aged and elderly people do not have competitive advantage in new industries such as IT, Internet with low education level. In this sense, the mechanization of Chinese traditional laborintensive industries is inevitable under the aging trend of traditional industries. As for work position, there were 7 team leaders who occupied 2.4 percent of all the participants, others were cleaners occupying 97.6 percent. Furthermore, all the participants were original from 7 teams. Team 7 had the most valid participants which included 60 memberships, occupying 20.8 percentage. Team 6 had the least valid participants that only occupies 10.0 percent with 30 memberships. Other teams had similar numbers of valid participants. The large management span is a disadvantage for labor-intensive company to conduct transformational leadership because leader is hard to realize the needs of every subordinates.

\subsection{The Correlation Analysis}

The aim of this study is to research whether transformational leadership has influence on team performance through empowerment and communication. In this part, the correlation analysis is conducted with Pearson's correlation coefficient to evaluate the relationship among the four factors. Pearson correlation coefficient, $r$, ranges from +1 to -1 . The more absolute 
value of Pearson's $r$ close to 1, the stronger correlation between two variables. And when the absolute value of Pearson's $r$ close to 0 , it means there is a weak association. In addition, when Pearson's $r$ is positive $(+)$, the value of one variable increases, the value of another variable shows the same trend, and vice versa (Pallant and Manual, 2013) ${ }^{[5]}$. In addition, the $p$ value is used to measure the significance of correlation coefficient that $\mathrm{p}$ value below 0.05 means strong correlation and below 0.001 means significant correlation.

TABLE II. CORRELATION BETWEEN TRANSFORMATIONAL LEADERSHIP AND EMPOWERMENT1

\begin{tabular}{|l|l|l|l|}
\hline & & Transformational leadership & Empowerment \\
\hline Transformational leadership & Pearson Correlation & 1 & $0.899^{\mathrm{m}}$ \\
\cline { 2 - 4 } & Sig. (2-tailed) & & 0.000 \\
\cline { 2 - 4 } & $\mathrm{N}$ & 288 & 288 \\
\hline \multirow{5}{*}{ Empowerment } & Pearson Correlation & $0.899^{\mathrm{m}}$ & 1 \\
\cline { 2 - 4 } & Sig. (2-tailed) & 0.000 & 288 \\
\cline { 2 - 4 } & $\mathrm{N}$ & 288 & 280 \\
\hline
\end{tabular}

Table2 describes the relationship between transformational leadership and empowerment. According to the table, it shows 95\% confidence of the strong correlation between transformational leadership. Because the $\mathrm{p}$ value is 0.000 which is less than 0.05 , the null hypothesis is rejected. Additionally, the Pearson's $\mathrm{r}$ is 0.9 closing to 1 , which means positive correlation between transformational leadership and empowerment. From this table, is can be found that the conduction of transformational leadership prompts the empowerment level in the case company.

TABLE III. CORRELATION BETWEEN EMPOWERMENT AND TEAm PERFormance2

\begin{tabular}{|c|c|c|c|}
\hline & & Empowerment & $\begin{array}{l}\text { Team } \\
\text { Performance }\end{array}$ \\
\hline \multirow[t]{3}{*}{ Empowerment } & $\begin{array}{l}\text { Pearson } \\
\text { Correlation }\end{array}$ & 1 & $0.785^{115}$ \\
\hline & $\begin{array}{l}\text { Sig. } \\
\text { tailed })\end{array}$ & & 0.000 \\
\hline & $\mathrm{N}$ & 288 & 288 \\
\hline \multirow{3}{*}{$\begin{array}{l}\text { Team } \\
\text { Performance }\end{array}$} & Pearson & $0.785^{m}$ & 1 \\
\hline & $\begin{array}{l}\text { Correlation } \\
\text { Sig. } \\
\text { tailed })\end{array}$ & 0.000 & \\
\hline & $\mathrm{N}$ & 288 & 288 \\
\hline
\end{tabular}

For measuring the relationship between empowerment and team performance, Pearson correlation coefficient is calculated. Table 4.2.3 (3) shows the $\mathrm{p}$ value is less than 0.001 and Pearson's $r$ is 0.784. Therefore, there is a positive and significant correlation between empowerment and team performance. In this sense, the empowerment in the team level is one of the factors that ensures the improvement of team performance.

Overall, transformational leadership has positive relationship with empowerment. And the empowerment also shows positive correlation with team performance in the case company.

\section{Conclusion}

Through the results of this study, transformational shows its advantages on promoting the team performance in the approach of empowerment. In China, most of the laborintensive industry enterprises show the preference of using regulation to manage the employees. However, bureaucracy stocks the communication between leaders and subordinates, which is negative to transformational leadership. Endowing more power to subordinates motivates employees to take more consideration about their own behaviour before action because they need to undertake the obligation by themselves. Yet, that gives more freedom to subordinates that encourages them to work effectively in their own way, especially in creation vocation. Overall, transformational leadership can be adopted in current Chinses enterprises.

\section{Reference}

1. Bass, B.M., 1990. From transactional to transformational leadership: Learning to share the vision. Organizational dynamics, 18(3), pp.19-31.

2. Dionne, S.D., Yammarino, F.J., Atwater, L.E. and Spangler, W.D., 2004. Transformational leadership and team performance. Journal of organizational change management, 17(2), pp.177-193.

3. Bell, E., Bryman, A. and Harley, B., 2018. Business research methods. Oxford university press.

4. Gupta, N.D., 1993. Probabilities of job choice and employer selection and male-female occupational differences. The American Economic Review, 83(2), pp.57-61.

5. Pallant, J. and Manual, S.S., 2013. A step by step guide to data analysis using IBM SPSS. Australia: Allen \& Unwin. doi, 10, pp.1753-6405. 